\title{
Obawa przed byciem sobą jako źródło niechęci wobec Inności? Problem indywiduacji młodzieży
}

Streszczenie: Artykuł ma na celu zwrócenie uwagi na dwa istotne zjawiska, które mogą być w pewien sposób ze sobą powiązane. Pierwszym z nich jest indywiduacja - stawanie się i bycie sobą. Drugim zaś niechęć wobec inności, odmienności, różnorodności. W odniesieniu do obu tych problemów stawia się pytanie badawcze: czy niechęć wobec inności może być wyrazem obawy przez stawaniem się indywiduum? Bycie jednostką autentyczną, autonomiczną i odpowiedzialną bycie sobą - stanowi dla wielu ludzi, szczególnie młodych, znaczące wyzwanie. Kształtowaniu (się) świadomości własnego istnienia jako odrębnej osoby towarzyszy formowanie określonego stosunku wobec innych ludzi. Warto jednak zbadać, w jaki sposób radzenie sobie z własnym „stawaniem się osobą”, przy jednoczesnym funkcjonowaniu w pewnych kontekstach społecznych, może oddziaływać na kształtowanie się postaw wobec inności. W badaniu stosuje się indywidualizującą perspektywę badawczą, skomponowaną m.in. na podstawie podejścia skoncentrowanego na osobie (person-centered approach) i wybranych założeniach egzystencjalnych.

Słowa kluczowe: osoba, indywiduacja, inność, młodzież, różnorodność

\section{I}

Niniejszy artykuł ma na celu zwrócenie uwagi na dwa istotne zjawiska, które mogą być w pewien sposób ze sobą powiązane. Pierwszym z nich jest indywiduacja - stawanie się i bycie sobą. Drugim zaś niechęć wobec inności, odmienności, różnorodności. W odniesieniu do obu tych problemów stawia się pytanie badawcze: czy niechęć wobec inności może być wyrazem obawy przez stawaniem się indywiduum? Bycie jednostką autentyczną, autonomiczną i odpowiedzialną - bycie sobą - stanowi dla wielu ludzi, szczególnie młodych, znaczące wyzwanie. Zakłada się, iż funkcjonowanie w specyficznych środowiskach społecznych - a to na przykład w kolejnych środowiskach 
szkolnych, w grupach towarzyskich w miejscu zamieszkania, a także w rodzinie - może przyczyniać się do ukierunkowywania indywidualnego rozwoju. Wykształcaniu świadomości własnego istnienia jako odrębnej osoby towarzyszy formowanie określonego stosunku wobec innych ludzi. Warto jednak zbadać, w jaki sposób radzenie sobie z własnym „stawaniem się osobą" u osób młodych może oddziaływać na kształtowanie się postaw wobec inności.

W artykule prezentuje się istotę badania poświęconego tej właśnie kwestii. Badanie znajduje się aktualnie we wstępnej fazie realizacji. Biorąc to pod uwagę, zdecydowano się przedstawić jedynie jego „rdzeń”: interesujące autora problemy i ich aspekty, hipotezy odnoszące się do ich źródeł, stawiane pytania, perspektywę badawczą. Świadomie zrezygnowano z licznych odwołań do bogatego piśmiennictwa, z wyjątkiem tylko tych miejsc, gdzie było to niezbędne. Niniejszy szkic ma więc stanowić raczej zasygnalizowanie pewnych kwestii oraz zachętę do szerszej dyskusji. Debata nad podniesionymi problemami, jak również nad zasadnością przyjmowanej perspektywy badawczej, stawianych pytań itd., może przyczynić się do podjęcia kolejnych, pogłębionych badań.

Artykuł składa się z następujących części. Pierwszą stanowi powyższe wprowadzenie, określające cele artykułu. W części drugiej objaśnia się szczegółowo przedmiotowe zagadnienie oraz powody jego doboru; tłumaczy się także ważniejsze terminy. Część trzecia odnosi się do metodologicznych aspektów badania. Artykuł wieńczy rekapitulacja.

\section{II}

Dobór zagadnienia związany jest przede wszystkim z następującymi dwoma powodami. Pierwszym jest zaobserwowany negatywny stosunek do odmienności i różnorodności wśród grupy uczniów. Tenże negatywny stosunek przejawiał się przez wyrażanie nieprzychylnych i radykalnych ocen wobec sposobów życia odmiennych od własnego. Autor prowadzi lub prowadził zajęcia dydaktyczne w Jagiellońskim Uniwersytecie Trzeciego Wieku, zajęcia dla uczestników studiów licencjackich i magisterskich na Uniwersytecie Jagiellońskim, a także zajęcia dla młodzieży licealnej w jednej z krakowskich placówek wychowania pozaszkolnego. To właśnie w ostatniej z grup ujawniły się opinie, które wydały się zastanawiające przede wszystkim w kontekście całokształtu wyrażanych przez dane osoby ocen i przekonań. O tym więcej w dalszej części tekstu (przykład z freewriting). Wspomnianą grupę zajęciową 
tworzyli uczniowie z pierwszych i drugich klas liceów ogólnokształcących. Przedmiot zajęć to: „Politologia i stosunki międzynarodowe”. Autorski kurs został skomponowany tak, aby uczniowie byli świadomi i potrafili identyfikować zasadnicze wyzwanie polityki. Wyzwaniem tym jest następujący dylemat: jak pogodzić różnorodne interesy, sposoby życia i wartości? Jak pogodzić coś, co może się wzajemnie wykluczać? W trakcie kolejnych spotkań posługiwano się pewną propozycją teoretyczną, iż polityka to zarządzanie sprzecznościami oraz tworzenie pewnej przestrzeni, w której mogą współistnieć różnorodne sposoby życia, związane z nimi różnorodnie rozumiane i różnorodnie wywodzone wartości. Przyjmując taką (pluralistyczną) podstawę wspólnej refleksji nad polityką, stworzono jednocześnie sposobność ujawniania się różnorodnych opinii. Takie tematy spotkań, jak: moralność i polity$\mathrm{ka}$, ideologie polityczne, polityka w ujęciu liberalnym, autonomia i wolność, demokracja, pluralizm etyczny, nowe ruchy społeczne, skutecznie zachęciły uczestników do aktywnej dyskusji. Były to także sytuacje, podczas których niektórzy uczniowie wyrażali stanowcze i krytyczne argumenty. Przykłady:

- „Ja ich nie rozumiem, jak można żyć w ten sposób?”;

- „Jestem Polakiem, chcę żyć w swoim kraju”;

- „Różnorodność - tak, ale w jakichś rozsądnych granicach”;

- „Im więcej różnorodności, tym potencjalnie więcej konfliktów”.

Przytoczone słowa są oczywiście wydobyte z szerszego kontekstu zarówno pojedynczej dyskusji, jak i całokształtu kursu, niemniej jednak pozwalają zwrócić uwagę na pewne aspekty nie tylko stosunku wobec inności, ale także uczniów wobec siebie samych i swego otoczenia. Już tylko w tych czterech przykładach opinii ujawniły się: kwestia zrozumienia, jak się żyje w pewien sposób (przykład pierwszy); kwestia „swojej”, własnej przestrzeni (przykład drugi); kwestia "granic” różnorodności (przykład trzeci); kwestia konfliktów (przykład czwarty). Widoczne są określone potrzeby. Są to mianowicie: potrzeba zrozumienia (ewentualnie: potrzeba akceptacji); potrzeba „własności” (ewentualnie: potrzeba własnego, akceptowanego przez innych sposobu bycia); potrzeba postępowania wedle własnych reguł, a nie funkcjonowania wyłącznie w granicach zakreślonych przez innych; obawa przed nieuchronnymi konfliktami, które z natury rzeczy mogą wiązać się z trudnymi wyborami. Jest to oczywiście jedna z wielu możliwych i uprawnionych interpretacji. Nie musi ona być słuszna. Prawdą jednak w tym kontekście jest to, co rzeczywiście czuje dana osoba, i to, jak jej świat wewnętrzny wpływa na jej działanie. To wszystko jednak właśnie jest przedmiotem zasygnalizowanego wyżej 
badania. Co ciekawe, potrzeby, o których mowa wyżej, zostały kilkakrotnie potwierdzone w grach dydaktycznych, opartych na metodach nauczania języków obcych. I tak na przykład stosując tzw. freewriting uczniowie pisali, czym jest wolność (mieli na to zadanie około trzech minut). Okazało się, że żadna z osób nie podała jakiejkolwiek spójnej definicji ani jej rozwinięcia, lecz odwołując się do własnego doświadczenia, uczestnicy gry podawali, że wolność to np.: „swoboda od czyichś nakazów”, „przyzwolenie na to, żeby móc robić to, czego się naprawdę pragnie”, „nieograniczanie się do tego, co nam każą inni”, „bycie tym, kim się chce, a nie takim, jak chcą inni”.

Istnieje także drugi - uzupełniający powyższe wyjaśnienia - powód takiego doboru zagadnienia, jak wskazane w tytule artykułu. Jest to „egzystencjalny” aspekt procesu „stawania się sobą", który wydał się autorowi szczególnie interesujący. Nie chodzi bynajmniej wyłącznie o przechodzenie określonych etapów rozwojowych (pozostawia się ten problem domenie psychologii rozwojowej), socjalizację itd. Egzystencjalna perspektywa pozwala skupić uwagę na takich aspektach istnienia, jak m.in.: „uczenie się” wolności poprzez korzystanie z niej i dokonywanie trudnych wyborów dotyczących siebie samego; potrzeba pewnej struktury, na której można się oprzeć, gdy nie ma nic pewnego; konieczność samookreślenia; indywidualizacja; usamodzielnianie, radzenie sobie z poczuciem odrębności. Perspektywa ta jest indywidualizująca, nakreśla inne ujęcie podniesionego problemu, może sprzyjać - jak się wydaje - lepszemu zrozumieniu złożoności analizowanej problematyki. Młodzi ludzie, którzy bezpośrednio zainspirowali wskazane badanie, stają w obliczu trudnej sytuacji. Mając 16-18 lat, zderzają się z oczekiwaniami, prośbami, nakazami otoczenia. Co więcej, trudność tego położenia wynika również z tego, iż osoby te - jak znaczna część ich rówieśników - muszą wybierać drogę życiową. Mierzą się więc z niepewnością odnośnie tego, co będzie, jakie rezultaty dadzą ich wybory. Zostają mimowolnie uwikłani w bardzo złożony i wymagający konflikt między oczekiwaniami i powinnościami $\mathrm{z}$ jednej strony a własnymi aspiracjami, chęciami, pragnieniami z drugiej. Pojawia się znaczący dylemat: „Co wybrać? To kim chcą, żebym był / kim powinienem być / kim chcę być / kim mogę być?”. Ujawnia się tu zasadnicze pytanie egzystencjalne: czy te trudności życia stojące przed młodymi ludźmi nie oddziałują na wykształcanie się stanowiska nieprzychylnego, wrogiego i/ lub lękowego wobec inności?

Nawiązując do powyższego pytania, rozważać można kolejne kwestie. Na przykład: czy jeśli odpowiedź na tamto pytanie byłaby twierdząca, to czy 
wykształcenie się takiego nieprzychylnego stanowiska wobec inności mogłoby być skutkiem „walki” między kształtującym się i pragnącym w końcu nabrać jakieś spójnej formy Ja a niestałością i płynnością, które cechują różnorodność? Indywiduacja może budzić pewne obawy. Jedną ze „strategii” ich przezwyciężania może być „roztapianie się” w grupie (ona zwykle dodaje pewności poczynaniom jej członków) poprzez intensyfikację relacji, częstotliwość spotkań itp. Czy jednak nie powoduje to zablokowania indywiduacji lub "zniekształcenia” jej (tj. samodzielnego kształtowania siebie) przez schematy grupowe? Są to oczywiście na razie jedynie hipotetyczne pytania wymagające weryfikacji. Niemniej podniesiony tu problem można w skrócie scharakteryzować następująco:

Schemat 1. Osoba uczestniczy w egzystencjalnym konflikcie:

dąży do:

stania się osobą określoną, taką, jaką chce, spójną, a także potwierdzoną (zaakceptowaną) przez innych,

przy czym staraniom tym towarzyszy obawa zarówno przed własną indywidualnością, jak i przed ewentualnym brakiem akceptacji

\section{jednocześnie:}

inni jawią się jako „różni”, „odmienni”, ale przy tym są „jacyś” - są określeni, konkretni;

pojawiać się może lęk przed konfliktem z NIMI oraz przed nieznośnym poczuciem niespójności W DANEJ OSOBIE w obliczu względnej spójności grupy

Zmagając się z takim konfliktem egzystencjalnym, jednostka w pełni odczuwa ciężar i znaczenie pytania: „Kim jestem?”.

Rozwijając powyższy problem, warto zwrócić uwagę na wciąż hipotetyczny, ewentualny model przebiegu takiego rodzaju konfliktu egzystencjalnego oraz jego implikacji (por. schemat 2).

Wskazano powyżej dwa powody, czy też dwie inspiracje do podjęcia badania. Wiążą się z nimi liczne hipotezy, pytania, wątpliwości. Na tym etapie opisu pozostaje jeszcze pokrótce wyjaśnić dwa terminy, które mogą wydać się Czytelnikowi niejasne. Pod pojęciem „młodzież” rozumie się tu uczestników zajęć pozaszkolnych (dodatkowych), o których mowa była wcześniej; są to osoby w wieku 16-18 lat, uczęszczają do krakowskich liceów ogólnokształcących. Podjęte badanie nie polega jednak na selekcji uczniów, wyborze części $\mathrm{z}$ nich do badania. Z perspektywy badania ważni są nie tylko ci uczniowie, których opinie uważa się za „kontrowersyjne”, ale cała grupa danego wykładowcy. Ważne jest, aby możliwie wiele grup zajęciowych uczestniczyło w badaniu. „Indywiduacja” pojmowana jest nie tyle jako rozwój psychiczny w ujęciu C. G. Junga, ale szerzej - jako stawanie się osobą niezależną, auten- 
tyczną, otwartą na doświadczenia własne i innych, świadomą swej osobności, podmiotowości i wolności, a także osobności, podmiotowości i wolności innych osób. Na gruncie tak rozumianej indywiduacji pytaniem o kluczowym dla osoby znaczeniu i wpływie jest: „Kim w istocie jestem?”. Takie kategorie jak: „lęk”, „niechęć” itp., stosuje się umownie, jako terminy robocze. Może się bowiem okazać, że stosunek niektórych młodych osób - tzn. tych wyrażających krytyczny, negatywny stosunek do inności, polega na czymś innym i terminy takie jak „lęk” czy „niechęć” mogą nie odpowiadać tym indywidualnym doświadczeniom.

Schemat 2. Model przebiegu konfliktu egzystencjalnego oraz jego implikacji

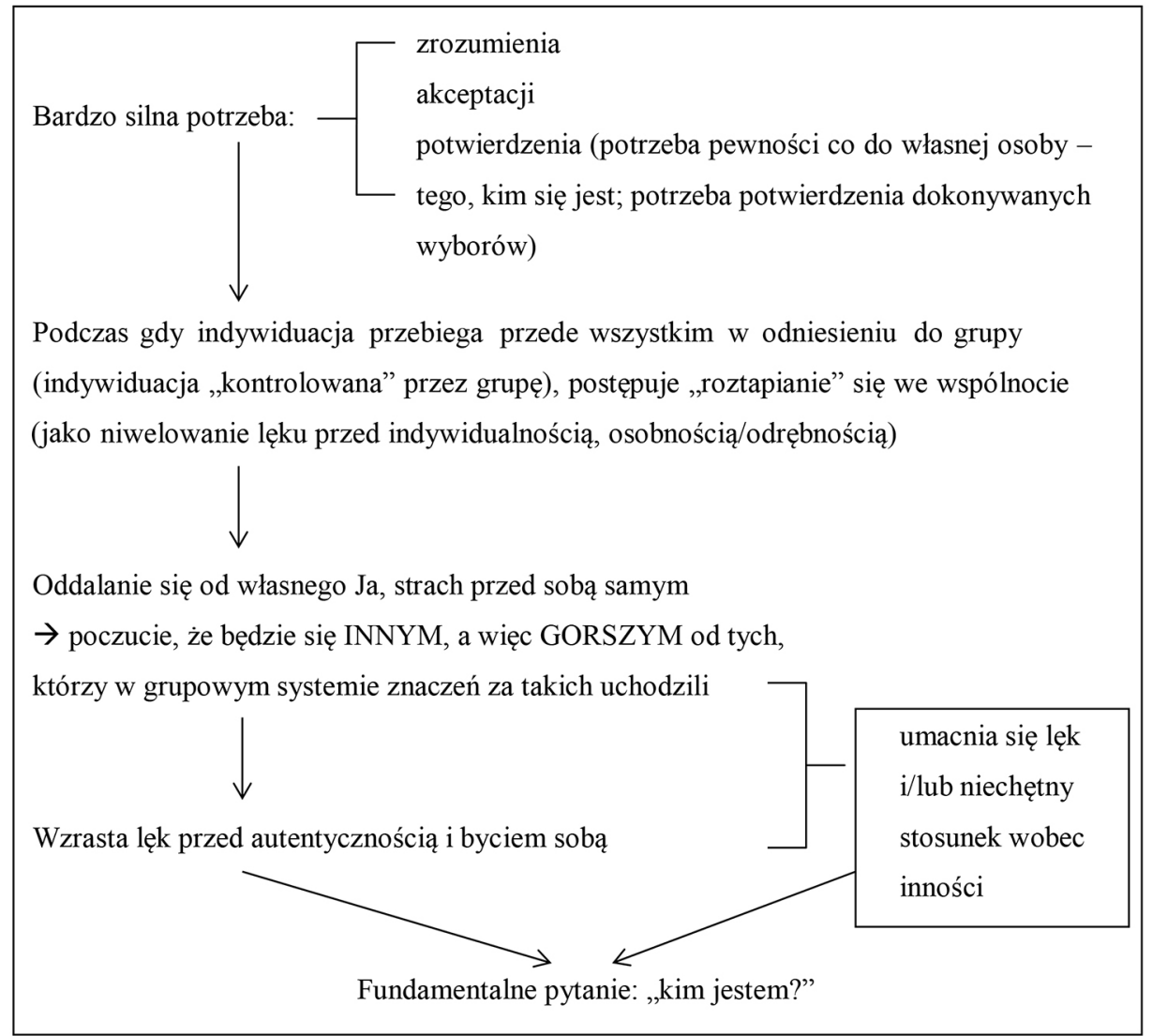




\section{III}

Pytanie badawcze odnoszące się do opisywanej problematyki brzmi: Czy niechęć (lub też lęk, nienawiść, inne negatywne odczucia) względem inności wynikają z obawy przed autentycznym byciem sobą? W tym kontekście istotne wydaje się m.in.: uchwycenie i zrozumienie myśli i emocji, które stoją za określonymi postawami; odkrycie obrazu siebie (obrazu własnego danej osoby); zrozumienie, jak dana osoba „staje się, jak widzi swój rozwój, jakie są konstytutywne elementy tego rozwoju, co go pobudza i w którym kierunku zmierza; sprawdzenie, czy oraz jak znajomość siebie i skłonność do swobodnej, autentycznej ekspresji swojego doświadczenia wpływa na stosunek do innych ludzi. Tak zakreślone pole badawcze implikuje konieczność ściśle indywidualizującego podejścia do osoby i jednocześnie bardzo elastycznej formy interakcji (wiele rodzajów wywiadów badawczych nie znajduje więc zastosowania w opisywanym badaniu). Oto, jakie wyzwania natury „metodologicznej" stoją przed badaczem. Pierwszym jest stworzenie takiej relacji, w której rozmówcy: będą mogli swobodnie, autentycznie wyrażać i przeżywać swoje opinie, postawy, uczucia; doświadczą swobody prezentowania swych poglądów i emocji; będą mogli być kongruentni, czyli spójni i konsekwentni w zakresie swych myśli, uczuć i działań; doznają bezwarunkowej akceptacji; spotkają się z empatycznym słuchaniem oraz ze wzajemnym zrozumieniem. Drugim zadaniem jest wczucie się w emocje „stojące” za słowami. Kolejnym jest dotarcie do własnej koncepcji siebie danej osoby i „wydobycie” tej koncepcji, wypowiedzenie jej. Zakłada się, że realizacja tych zadań, opierająca się na aktywnym zaangażowaniu wszystkich rozmówców, doprowadzi do swoistej konfrontacji autentycznej koncepcji siebie danej osoby z koncepcją "Ja-dla-innych". Komponentami obu tych koncepcji jest również stosunek wobec innych ludzi. Warto dodać, że jedynie „przejrzysta” i swobodna relacja pozwoli zrozumieć, co jest przeżywane i wyrażane. Przyjmuje się, że tylko taka relacja pozwoli dojść do indywidualnej prawdy, która jest przeżywana przez daną jednostkę. Prawda w tym kontekście zostaje sprowadzona do tego, kim jest dana osoba; jak ona żyje; co może, co musi, co powinna, czego się od niej oczekuje; jaki jest jej obraz innych ludzi, z którymi żyje, i jaki jest ich obraz INNYCH, który to obraz może ta osoba może podzielać.

Opisane powyżej stanowisko metodologiczne opiera się na tzw. podejściu skoncentrowanym na osobie (person-centered approach; za jego twórcę po- 
wszechnie uznaje się C. R. Rogersa) ${ }^{1}$. Jest więc związane wprost z psychologią humanistyczną. Wszystkie elementy i pryncypia podejścia skoncentrowanego na osobie znalazły wyraz w przyjętej perspektywie badawczej, a są to: autentyczność, bezwarunkowa akceptacja, empatia, a także: niedyrektywność (ze strony badacza), wydobycie koncepcji siebie, dążenie do samoświadomości² Nie istnieje tu zagrożenie pomieszania metod terapeutycznych z metodami badawczymi. Opisane wyżej podejście ustala pewne warunki relacji, czy też: jest ono po prostu pewnym typem relacji, a nie wyłącznie rodzajem terapii ${ }^{3}$. Jako że w badaniu zmierza się m.in. do określenia konstruktów osobistych, pewne zastosowanie znajduje w tym kontekście również technika identyfikacji kontstuktów osobistych (tzw. Rep Grid) ${ }^{4}$. Jest ona jednak relatywnie bardziej ustrukturyzowanym rodzajem badania, aniżeli elastyczna (choć bardzo wymagająca) relacja oparta na person-centered approach.

\section{IV}

Cechą charakterystyczną opisanego badania jest jego indywidualizujące, egzystencjalne i humanistyczne nastawienie. Pozwala ono rozpoznać pewne problemy i spojrzeć na nie przez szczególny pryzmat. Indywiduacja jest tym rodzajem doświadczenia, które dotyczy nie tylko ludzi młodych. Może być jednak przez nich szczególnie przeżywane. Warto zatem poddać badaniu sposób, w jaki przeżywa siebie, stawanie się sobą, odbywające się w pewnych kontekstach społecznych, oddziaływać może na kształtowanie jednostkowego stosunku wobec inności, odmienności i różnorodności.

1 Zob. zwłaszcza D. Mearns, B. Thorne: Terapia skoncentrowana na osobie. Kraków 2010, UJ, s. 7 i n.; C. R. Rogers: Sposób bycia. Poznań 2012, „Rebis”, s. 21-41, 127-149; C.R. Rogers: O stawaniu się osoba. cyt. wyd., s. 55-66.

2 D. Mearns, B. Thorne: Terapia skoncentrowana na osobie. cyt. wyd., s. 9-18; C. R. Rogers: O stawaniu się osobą. cyt. wyd., s. 41-54; C. R. Rogers: Sposób bycia. cyt. wyd., s. 21-41, s. 127-149.

3 Zob. np. C. R. Rogers: O stawaniu się osoba. cyt. wyd., s. 58, 64.

4 D. Bourne, D. A. Jankowicz: Technika identyfikacji konstruktów osobistych. W: D. Jemielniak: Badania jakościowe. Metody i narzędzia. Tom 2 (tłum. M. Höffner). Warszawa 2012, Wydawnictwo Naukowe PWN, s. 221-245. 


\section{Bibliografia}

Bourne D., Jankowicz D. A.: Technika identyfikacji konstruktów osobistych.

W: D. Jemielniak: Badania jakościowe. Metody i narzędzia. Tom 2. Warszawa 2012, PWN.

Mearns D., Thorne B.: Terapia skoncentrowana na osobie. Kraków 2010, UJ. Rogers C. R.: Uczyć się, jak być wolnym. W: K. Jankowski: Przełom w psychologii. Warszawa 1978, „Czytelnik”.

Rogers C. R.: Sposób bycia. Poznań 2012, „Rebis”.

Rogers C. R.: O stawaniu się osobą. Poznań 2014, „Rebis”.

Yalom I.: Psychoterapia egzystencjalna. Warszawa 2008, Instytut Psychologii Zdrowia, Polskie Towarzystwo Psychologiczne.

Yalom I.: Kat miłości. Opowieści psychoterapeutyczne. Warszawa 2013, Wydawnictwo „Czarna Owca”.

\section{A fear of being oneself as a source of unwillingness towards Otherness? The problem of individualization of youth}

\section{Summary}

The purpose of this article is to pay close attention to two important phenomena which could be related. The first one is the individuation - becoming a person as well as being oneself. The second is antipathy towards otherness and diversity. In reference to both phenomena, the following research question is raised: could antipathy towards otherness be an expression of one's own fear of becoming an individual? Being an authentic, autonomic and responsible person - being oneself - is indeed a challenge, especially for young people. Creation of a certain attitude towards other people is accompanied by raising consciousness of one's own being a separate person. Therefore, it is worth conducting some research on how one's "becoming a person" (while functioning in a certain social context) may affect forming individual attitudes towards otherness. In the undertaken research, an individualistic perspective is used, consisting in the person-centered approach and selected existential principles.

Key words: diversity, individuation, otherness, person, youth 